\title{
Rachitogenic Effect of some Green Fodders for Sheep
}

\author{
By T. K. EwFr \\ Institute of Animal Pathology, University of Cambridge
}

The lameness, with an associated unthriftiness, which occurs amongst young sheep grazing various fodder crops during some winters, has long been known in the South Island of New Zealand. The stud-breeder over-wintering ram lambs, and trying to encourage maximum growth, has been most acquainted with this trouble.

The condition was shown to be true rickets (Fitch, 1943) and it is clinically recognizable by a pronounced hypophosphataemia, normal serum-calcium values, lack of growth, lameness showing first as a curious 'proppy' gait, with later enlargement of the knee joints and even plainly visible osseous deformity. A high correlation has been shown to exist between the intensity of the rachitic lesion and the degree of hypophosphataemia (Ewer \& Bartrum, 1948).

\section{Incidence of rickets}

Between 1943 and 1946 , trials were made to test the rachitogenicity of the commonly fed winter feeds, such as turnips, marrow-stem kale, Italian rye grass, young mixed pasture, as well as the green cereals, oats and barley. Using as main criteria the calcium and phosphorus values of the blood, $\mathrm{X}$-ray examination and measurement of the metacarpal epiphyses and costochondral junctions at death, Ewer \& Bartrum (1948) found that, whereas occasional sheep grazing turnips or kale showed evidence of rickets, and sheep kept on those feeds and treated with vitamin D made better weight gains, it was in sheep grazing either Italian rye grass or green cereals that the incidence of rickets was often very high and the effect of giving calciferol profound.

\section{Effect of vitamin $D$}

Vitamin $\mathrm{D}_{2}$, given in the form of a single massive dose of calciferol $(25 \mathrm{mg}$. orally in $20 \mathrm{ml}$. of olive oil), was completely effective in preventing or rapidly curing rickets. It also significantly increased growth, even when control sheep did not become rachitic.

The daily vitamin $\mathrm{D}$ requirement of similar sheep is $c$. I30 i.u. (Andrews \& Cunningham, 1946) but we found that supplementary intake of $c .300$ i.u. of vitamin $D_{3}$, given as cod-liver oil, did not entirely prevent rickets in hoggets grazing green oats.

\section{Intakes of calcium and phosphorus}

Analyses of the strongly rachitogenic green cereals in 1945 showed calcium oxide $(\mathrm{CaO})$ values ranging between 0.34 and $0.72 \mathrm{~g} . / 100 \mathrm{~g}$. and phosphorus pentoxide $\left(\mathrm{P}_{2} \mathrm{O}_{5}\right)$ values between 0.43 and $\mathrm{I} .08 \mathrm{~g}$. $/ 100 \mathrm{~g}$. Slightly higher values were obtained in 1946 when the incidence of rickets was greater. It is clear that a safety limit of $\mathrm{r} \cdot 6 \mathrm{~g}$. of $\mathrm{CaO}$ and $\mathrm{I}_{5} 5 \mathrm{~g}$. of $\mathrm{P}_{2} \mathrm{O}_{5}$ daily (Mitchell \& McClure, 1937) suggested for sheep of the weight used by us was well exceeded. Further, when supplementation with calcium 
and phosphorus at a high rate was tried on two occasions $(0.5 \mathrm{oz}$. of bone-flour per sheep twice weekly), no better growth rate resulted, although the amount and severity of rickets was reduced.

\section{Conclusion}

There is a relationship between a good season, more feed, greater growth by the sheep and high incidence of rickets, and it appears that the quantity of ultraviolet radiation is of less importance than the occurrence of some specific principle interfering with phosphorus metabolism in the growing sheep, found in highest concentration in green cereals.

\section{REFERENCES}

Andrews, E. D. \& Cunningham, I. J. (1946). N.Z. F. Sci. Tech. 27 A, 223.

Ewer, T. K. \& Bartrum, P. (1948). Aust. vet. F. 24, 73.

Fitch, L. W. N. (1943). Aust. vet. F. 19, 2.

Mitchell, H. H. \& McClure, F. J. (1937). Bull. nat. Res. Coun., Wash., no. 99.

\section{Imbalance of Fat-Soluble Vitamins}

\section{By ThOMas MoORE}

\section{Dunn Nutritional Laboratory, University of Cambridge and Medical Research Council}

Only a few instances are known in which the requirement for one fat-soluble vitamin has been found to be influenced by the intake of another vitamin of this group. If we interpret the scope of our title more comprehensively, however, we may consider the effects of toxic overdosage with one vitamin as being a form of imbalance, and may include also the effects of excess or deficiency of various other nutrients on the activity of the fat-soluble vitamins.

\section{Vitamin $A$}

Great excess of vitamin A when given to rats causes skeletal fractures and internal haemorrhages in various sites (Moore \& Wang, 1945). The symptoms resemble those of scurvy, and it has been claimed that treatment with vitamin $\mathrm{C}$ is beneficial (Vedder \& Rosenberg, 1938). Another link between these two vitamins might be inferred from the reduced synthesis of vitamin $C$ in vitamin A deficiency (Sure, Theis \& Harrelson, 1939), although others have found that this relationship is not specific (Mapson \& Walker, 1948-9). Mayer \& Krehl (1948), however, have claimed that the administration of vitamin $\mathrm{C}$ greatly prolongs the survival of rats kept on a diet deficient in vitamin $\mathrm{A}$, and Bassett, Loosli \& Wilke (1948) have reported that, by giving vitamin $\mathrm{C}$ to silver foxes kept on a diet deficient in vitamin A, symptoms of nervous inco-ordination were prevented. Experiments by the author and his colleagues have failed to indicate that ascorbic acid has any beneficial effect in deficiency or excess of vitamin $A$, and vitamin $\mathrm{D}$ also has been found ineffective in the treatment of hypervitaminosis $\mathrm{A}$.

The report of Light, Alscher \& Frey (1944) that a state of vitamin A excess induces in rats a low level of blood prothrombin which may be corrected by giving vitamin $\mathrm{K}$ 